\title{
МЕТОДОЛОГІЧНІ ПІДХОДИ ДО АНАЛІЗУ СИСТЕМИ ПІДГОТОВКИ НАУКОВО-ПЕДАГОГІЧНИХ КАДРІВ ЗАСОБОМ ПРИВАТ-ДОЦЕНТУРИ В УНІВЕРСИТЕТАХ УКРАЇНИ ДРУГОЇ ПОЛОВИНИ ХІХ - ПОЧАТКУ ХХ СТОЛІТТЯ
}

\author{
Таможська I. B. \\ доктор педагогічних наук, \\ дочент кафедри мовної підготовки № 1 \\ Навчально-науковий інститут міжнародної освіти \\ Харківського національного університету імені В. Н. Каразіна \\ майдан Свободи, 4, Харків, Україна \\ orcid.org/0000-0003-0865-2380 \\ itamozska@ukr.net
}

\author{
Ключові слова: \\ концеепція дослідження, \\ системний, циивілізаційний \\ та парадигмальний \\ методологічні підходи, \\ методологічні принциини, \\ система підготовки науково- \\ педагогічних кадрів.
}

У статті зазначено, що поняття «концепція дослідження» базується на наукових підходах, які визначають стратегію дослідницької та практичної діяльності, а термін «підхід» певною мірою зумовлений соціальним контекстом, що визначає зміст та спрямованість такої діяльності. Виокремлено методологічні принципи, що забезпечують системну спрямованість наукового дослідження і практичного пізнання об'єкта (цілісності, примату цілого над складовими частинами, ієрархічності, структурності, самоорганізації, взаємозв'язку із зовнішнім середовищем). Акцентовано увагу на тому, що предметом цивілізаційного підходу $\epsilon$ сукупність усіх форм життєдіяльності суспільства (матеріальних, ідейних, культурних, релігійних, моральних) у їхньому історичному розвитку й наступності. Висвітлено систематизацію парадигмальних підходів С. Бобришева (парадигмально-педагогічний, поліпарадигмальний, цивілізаційний, культурологічний, аксіологічний), в основу яких покладено концепції та теорії, що визначають детермінації суспільного розвитку людства. Підкреслено, що цивілізаційні підходи дозволяють відтворити провідні виміри історико-педагогічного процесу (власне історичний, соціокультурний, історичного розвитку освіти, педагогічного знання). Розглянуто особливості реалізації системного, цивілізаційного та парадигмального методологічних підходів у контексті аналізу системи підготовки науково-педагогічних кадрів засобом приватдоцентури в університетах України другої половини XIX - початку ХХ століття. Системний підхід сприяв тому, щоб виявити цільову, змістову, процесуальну, організаційну та технологічну цілісність у системі підготовки науково-педагогічних кадрів. Парадигмальний підхід дозволив дослідити зміну домінантних освітніх установок у підготовці науково-педагогічних кадрів у вітчизняних університетах України крізь призму провідних освітніх парадигм. Цивілізаційний підхід спрямував на виявлення передумов процесу запровадження кадрового інституту приват-доцентів у системі вищої освіти. 


\title{
METHODOLOGICAL APPROACHES TO ANALYZING THE SYSTEM OF ACADEMIC STAFF TRAINING BY MEANS \\ OF PRIVAT ASSOCIATE PROFESSORSHIP IN THE UNIVERSITIES OF UKRAINE IN THE SECOND HALF OF THE XIX - AT THE BEGINNING OF THE XX CENTURY
}

\author{
Tamozhska I. V. \\ Doctor of Pedagogical Sciences, \\ Associate Professor at the Language Training Department No. 1 \\ Institute of International Education for Study and Research \\ of V. N. Karazin Kharkiv National University in Ukraine \\ Svobody sq., 4, Kharkiv, Ukraine \\ orcid.org/0000-0003-0865-2380 \\ itamozska@ukr.net
}

Key words: research concept, systematic, civilizational and paradigmatic methodological approaches, methodological principles, system of academic staff training.
It is stated in the article that the notion "research concept" is based on scientific approaches that determine the strategy of research and practical activities, and the term "approach" is to some extent interrelated to the social context, which establishes the content and direction of such activities. The methodological principles that provide a systematic orientation of scientific research and practical cognition of the object (integrity, primacy of the whole over its components, hierarchy, structure, self-organization, interconnection with the external environment) are singled out. It is stressed that the subject of the civilizational approach is the integrity of all forms of social life activity (material, ideological, cultural, religious, moral) in their historical development and continuity. The article outlines the systematization of paradigmatic approaches suggested by S. Bobryshev (paradigmatic-pedagogical, polyparadigmatic, civilizational, culturological, axiological), which are based on the concepts and theories that establish the determinations of mankind social development. It is emphasized that civilizational approaches contribute to reproducing the leading dimensions of the historical and pedagogical process (actually historical, socio-cultural, historical development of education, pedagogical knowledge). The author considers the peculiarities of realizing systemic, civilizational and paradigmatic methodological approaches when analyzing the system of academic staff training by means of private associate professorship in the universities of Ukraine in the second half of the XIX - at the beginning of the XX century. The systematic approach contributed to identifying targeted, meaningful, procedural, organizational and technological integrity in the system of academic staff training. The paradigmatic approach helped to reveal the change of dominant educational attitudes in academic staff training in domestic universities of Ukraine in the light of leading educational paradigms. The civilizational approach was used to single out the preconditions for introducing the staff institute of private associate professors in the system of higher education.
Постановка проблеми у загальному вигляді. Забезпечення університетів висококваліфікованими кадрами, проведення атестації, організація дослідницької роботи є основою ефективної навчальної, наукової та методичної діяльності закладів вищої освіти. Історико-педагогічні дослідження теоретико-методичних засад підготовки науково-педагогічних кадрів в університетах України слугують підгрунтям для вибору найбільш ефективних засобів формування викладацьких колективів університетів.
Аналіз останніх досліджень і публікацій. Питанням методологічних основ наукового дослідження займалися О. Адаменко, В. Курило, В. Ковальчук, Л. Моїсєєв, І. Прєдборська, Я. Скалкова, Є. Хриков та ін. Особливості системного методологічного підходу висвітлено в наукових розвідках В. Ковальчук, В. Кохановського, Т. Кристопчук, Н. Кушнаренко, П. Образцова, С. Сисоєвої, В. Шейко; цивілізаційного та парадигмального підходів - у наукових працях В. Бєляєвої, C. Бобришова, О. Вознюка, О. Гукаленка, 
Г. Корнетова, Ю. Козловського, Л. Новікової, Е. Позднякова, В. Руденко. А втім особливості цих підходів до аналізу системи підготовки науково-педагогічних кадрів засобом приват-доцентури в університетах України другої половини XIX - початку XX століття залишились поза межами уваги науковців.

Мета статті - розглянути особливості реалізації системного, цивілізаційного та парадигмального методологічних підходів у контексті аналізу системи підготовки науково-педагогічних кадрів засобом приват-доцентури в університетах України другої половини XIX - початку XX століття.

Виклад основного матеріалу. Концепція дослідження - це головна ідея, визначальний задум, що орієнтує на остаточний результат i базується на наукових підходах, що визначають стратегію дослідницької та практичної діяльності [20, c. 68].

Ми погоджуємося $з$ думкою вчених (Ю. Загородній, В. Курило, С. Савченко), що поняття «підхід» значною мірою зумовлене соціальним контекстом, що визначає зміст, характер та спрямованість дослідницької діяльності, адже виступає як специфічна основа освітньої парадигми, фундамент іï концепції, указує на способи побудови тієї чи іншої освітньої системи $[7$, с. 90].

Розглянемо особливості реалізації системного та цивілізаційного методологічних підходів у контексті нашого дослідження. Кожен із підходів має свою специфіку, більшість із них представляють фундаментальні напрями, у яких синтезуються теоретичні положення, соціально-педагогічний досвід, створюються й апробуються прогресивні педагогічні моделі [7, с. 91].

Одним із завдань методології педагогічного дослідження є орієнтація на системний підхід, що передбачає розгляд об'єкта вивчення як системи: виявлення її елементів, встановлення їхнього взаємозв'язку з явищами, їхньої підпорядкованості, динаміки розвитку, сутності та особливостей, чинників та умов [15, с. 11-12].

Системний підхід, за визначенням професора В. Кохановського, - це сукупність загальнонаукових методологічних принципів (вимог), в основі яких лежить розгляд об'єктів як систем; він пов'язаний із принципом історизму насамперед через «онтологічні обставини», адже переважно це системи, що розвиваються [12, с. 277-279].

У педагогічній науці системний підхід спрямований на розкриття цілісності об’єктів, виявлення в них взаємозв'язків та «зведення їх у єдину теоретичну картину»; складові системи (підсистеми) можна розглядати як самостійні системи [6, c. 305].

Системний підхід визначає принцип розчленування багатокомпонентних об'єктів дослідження, виходячи з того, які зв' язки є найважливішими для системи за наявності різноманітних типів кожної конкретної системи. На такому підгрунті досліджуються основні властивості системного об'єкта в нерозривному зв'язку структури та функції в іiї динаміці $[9$, с. 60].

Як зазначають С. Сисоєва та Т. Кристопчук, «системний підхід виходить із того положення, що специфіка складного об'єкта (системи) не вичерпується особливостями елементів, що іiі становлять, а пов'язана передусім із характером взаємодії між елементами», а тому «на перший план виходить завдання пізнання характеру й механізму цих зв'язків і відношень», зокрема людини та суспільства, людей у певному співтоваристві [23].

Науковці (В. Шейко та Н. Кушнаренко) виокремлюють низку методологічних принципів, що забезпечують системну спрямованість наукового дослідження й практичного пізнання об'єкта, а саме: цілісності (досліджуваний об'єкт розчленовується на окремі частини, органічно інтегровані в єдине ціле), примату цілого над складовими частинами (функції окремих компонентів і підсистем підпорядковані функції всієї системи, а також меті), ієрархічності (постулює підпорядкованість компонентів і підсистем усій системі; супідрядність систем нижчого рівня системам більш високого рівня, унаслідок чого предметна галузь теорії набуває ознак ієрархічної метасистеми), структурності (закономірний зв'язок між частинами цілого, що забезпечує єдність системи, зумовлює особливості її внутрішньої будови), самоорганізації (динамічна система іманентно здатна самостійно підтримувати, відтворювати або вдосконалювати рівень своєї організації в процесі зміни внутрішніх та зовнішніх умов іiї існування, функціонування задля збереження цілісності, забезпечення ефективних дій та розвитку), взаємозв'язку iз зовнішнім середовищем (система не є самодостатньою, адже вона постійно змінюється та удосконалюється відповідно до змін зовнішнього середовища) [28, с. 62].

В інтегративному аспекті розгляду системи велике значення мають ті елементи та взаємозв'язки, що зберігають спільність системи, об'єднують (інтегрують) елементи, сприяють ії̈ збереженню й функціонуванню [24, с. 181].

Зазначені положення системного підходу дають змогу всебічно проаналізувати складник загальної системи безпосередньої освіти особистості - підготовку науково-педагогічних кадрів засобом приват-доцентури як цілісного педагогічного феномена, який має взаємопов'язані складники, сутнісні характеристики (зокрема, підвищення професійного рівня педагогічної майстерності та наукової кваліфікації, забезпечення високого науково-теоретичного та методичного 
рівня викладання дисциплін відповідної спеціальності, відрядження до закладів вищої освіти та освітніх установ Західної Європи «з науковою метою», захист дисертацій, проведення наукових досліджень, представлення науково-педагогічної діяльності шляхом наукових доповідей, публікацій тощо) та виконує програмно-цільові та процесуально-технологічні функції, що підпорядковані певній меті, - забезпеченню університетів України другої половини XIX - початку XX століття кадрами вищої кваліфікації. Цей підхід дав підстави до аналізу результативності інституту приват-доцентури, інституту «професорських стипендіатів», закордонних "відряджень із науковою метою» щодо підготовки кадрів вищої кваліфікації. Отже, розглядати процес підготовки науково-педагогічних кадрів засобами приватдоцентури як інтегровану педагогічну систему дає підстави й те, що їй притаманні ознаки системи (цілісність, структурність, взаємозалежність системи та зовнішнього середовища, ієрархічність, багатоваріантність опису системи) [25].

Для історико-педагогічного дослідження важливим $є$ застосування цивілізаційного підходу, предметом якого $\epsilon$ «сукупність усіх форм людської життєдіяльності того чи іншого суспільства - матеріальних, ідейних, культурних, релігійних, моральних... - у їхній єдності та нерозривності, у їхньому історичному розвитку й наступності» [18, с. 53].

I. Прєдборська відзначає зростання суб'єктивного чинника в процесі історичного поступу: суб'єкт і його діяльність стають основою історичного розвитку. «Історія стає подієвою, а події людиновимірними» $[19$, с. 3$]$.

Цивілізаційний підхід дозволяє «фіксувати переломний рубіж у розвитку людства» і на основі вичленовування атрибутивних ознак цивілізації реконструювати низку закономірностей, властивих суспільству [14, с. 20].

Цивілізаційний підхід являє собою новий рівень у розробці проблеми інтеграції наукового знання в дослідженні історико-педагогічного процесу; дозволяє здійснити перехід від загального через спільне й особливе до поодинокого і навпаки, що сприяє впорядкованій науковій класифікації та типологізації педагогічних явищ i систем, виокремленню спільного в розвитку всесвітньо-історичного процесу (В. Бєляєв) [2, с. 23].

Цей дослідницький підхід визначає зв'язок історизму з домінуючим типом культури (О. Вознюк) $[5$, с. 4]; «допомагає чітко виділити спільні характеристики і такі важливі риси наступності в історичному розвитку суспільства...» (Р. Ентов) $[29$, с. 21$]$; здатний забезпечити теоретичну цілісність бачення вітчизняного історико-педагогічного процесу (А. Павко, Л. Курило) [16, с. 74]; сприяє виробленню цілісного концептуального погляду на природу єдності й різноманіття історико-педагогічного процесу, суголосного реаліям сучасності, коли людство рухається до світової цивілізації, зберігаючи національно-регіональну своєрідність (Г. Корнетов) [11, с. 151]; націлює дослідника на розгляд основних положень педагогічної теорії та освітньої практики в контексті цивілізаційної еволюції людства (В. Мокляк) $[13$, с. 120]; уможливлює розгляд об'єкта дослідження як нелінійного процесу у складі самобутніх європейських цивілізацій (Л. Зеленська) [8].

Отже, положення цивілізаційного підходу дають можливість простежити передумови процесу запровадження кадрового інституту приват-доцентів у системі європейської вищої освіти, а також довести, що науково-дослідна діяльність $\epsilon$ однією 3 найважливіших складових частин освітнього процесу, що забезпечує залучення науково-педагогічних кадрів університетів України другої половини XIX - початку XX століття до останніх досягнень науково-технічного прогресу й підтримує високий рівень викладання, адекватний економічним потребам тогочасного суспільства.

Доцільним уважаємо використання парадигмального підходу. Поняття «парадигма» тлумачиться як сукупність філософських, загальнотеоретичних основ науки; система понять та уявлень, які властиві певному періодові розвитку науки, культури, цивілізації [3]; як теорія (або модель постановки проблеми), прийнята як зразок вирішення дослідницьких завдань [26, с. 477].

У дослідженні О. Сергєєва зазначено, що парадигма як вихідна концептуальна схема, місія, матриця освітньої системи є основою державної освітньої політики, що забезпечує перспективи розвитку суспільства [22, с. 15$]$.

В освітньому процесі парадигмальні підходи, на думку В. Руденко та О. Гукаленко, відображають співвідношення цінностей культури і цивілізації, а також цінностей особистості та соціуму $[21$, c. 33$]$.

Як констатує О. Вознюк, парадигмальний підхід реалізує дослідження парадигмального знання в історичній науці та події, що відбувалися упродовж ста років, із погляду тих або інших наукових парадигм, визначаючи зв'язок історизму з домінуючим типом світогляду [5, с. 4].

Парадигмальний підхід передбачає розгляд внутрішньої логіки розвитку педагогіки з погляду виникнення, трансформації, взаємодії різних парадигм - цілісних концепцій, що базуються на особливих онтогенетичних та гносеологічних ідеалізаціях й установках, поширених у науковому товаристві, що здатні по-новому організувати підгрунтя науки (О. Адаменко) [1, с. 13]. 
Поєднання ціннісних орієнтацій, теоретичних ідей, методів і засобів наукового дослідження, як уважає Л. Хомич, є сутнісною характеристикою парадигмального підходу [17, с. 172].

Парадигмальний підхід дозволяе виокремлювати етапи розвитку педагогічного явища $[27$, c. 94]; установити їхні загальні закономірності та визначити специфічні особливості [12, с. 224].

Ю. Козловський наголошує на тому, що парадигмальний підхід зобов'язує розглядати логіку розвитку ідеї певного педагога 3 позиції самої науки, iii внутрішньої динаміки, із погляду виникнення й трансформації різних ідей, положень, постулатів, вироблених особою або особами, які вважалися членами окремої науково-педагогічної спільноти, що діяла деякий час у певному просторі [10, с. 81].

До парадигмальних підходів С. Бобришев відносить парадигмально-педагогічний, поліпарадигмальний, цивілізаційний, культурологічний та аксіологічний, в основу яких покладено визнані наукові концепції та теорії, що визначають детермінації суспільного розвитку людства. Ці підходи дозволяють відтворити провідні виміри історико-педагогічного процесу, а саме: власне історичний (фіксує якісну визначеність історико-педагогічного процесу); соціокультурний (спрямовує на різні суспільні передумови та обставин (класові, економічні, соціальні, політичні, релігійні) історичного розвитку освіти та педагогічного знання). Парадигмально-педагогічний та поліпарадигмальний підходи орієнтовані на виокремлення в масиві педагогічних фактів та феноменів стійких визначених внутрішніх властивостей, що дозволяють їх згрупувати, порівняти, розробити типологію. Цивілізаційний, культурологічний та аксіологічний підходи будуються на різних соціокультурних засадах взаємопов'язаного функціонування й розвитку суспільства, зокрема й педагогічної сфери, забезпечують збагачення педагогічної теорії та практики ємними соціокультурними смислами $[4$, c. $20-21]$.

Зазначені положення парадигмального підходу дали можливість дослідити зміну домінантних освітніх установок у підготовці науково-педагогічних кадрів в університетах України другої половини XIX - початку XX ст.

Висновки. Отже, системний, цивілізаційний та парадигмальний підходи до аналізу системи підготовки науково-педагогічних кадрів засобом приват-доцентури в університетах України другої половини XIX - початку XX століття взаємопов'язані та взаємодоповнюють один одного, дають змогу розкрити цілісність розгортання зазначеного питання в логіко-проблемній послідовності.

\section{ЛІТЕРАТУРА}

1. Адаменко О.В. Розвиток педагогічної науки в Україні в другій половині XX століття (1950-2000рр.) : автореф. дис. ... д-ра пед. наук : 13.00.01. Луганський національний педагогічний університет імені Тараса Шевченка. Луганськ, 2006. 44 с.

2. Беляев В.И. Современные подходы в историко-педагогических исследованиях. Педагогика. Москва, 1999. № 6. C. 19-25.

3. Бибик С.П., Сюта Г.М. Словник іншомовних слів : тлумачення, словотворення та слововживання. Харків : Фоліо, 2006. 623 с.

4. Бобрышов С.В. Методология историко-педагогического исследования развития педагогического знания : автореф. дисс. ... д-ра. пед. наук : 13.00.01. Санкт-Петербург, 2007. 45 с.

5. Вознюк О.В. Нова парадигма моделювання та розвитку історико-педагогічного процесу. Житомир : ЖДУ ім. І. Франка, 2014. 550 с.

6. Гончаренко С.У. Український педагогічний словник. Київ : «Либідь», 1997. 374 с.

7. Загородній Ю.І., Курило В.С., Савченко С.В. Політична соціалізація студентської молоді в Україні : досвід, тенденції, проблеми. Київ : Генеза, 2004. 144 с.

8. Зеленська Л.Д. Учені ради у системі діяльності університетів України XIX століття : дис. ... д-ра пед. наук : 13.00.01. Харків, 2012. 612c.

9. Ковальчук В.В., Моїсєєв Л.М. Основи наукових досліджень : навчальний посібник. Київ : ВД «Професіонал», 2004. $216 \mathrm{c.}$

10. Козловський Ю.М. Методологія педагогічного дослідження : навчальний посібник. Львів : Вид-во Львівської політехніки, 2018. 196 с.

11. Корнетов Г.Б. Педагогика : теория и история. Москва : Изд-во УРАО, 2003. 296 с.

12. Кохановский В.П. Философия и методология науки. Ростов-на-Дону : Феникс, 1999. 576 с.

13. Мокляк В.М. Розвиток автономії в університетах України (XIX - початок XX століття) : дис. ... д-ра пед. наук : 13.00.01. Полтава, 2019. 641 с.

14. Новикова Л.И. Цивилизация как идея и как объяснительный принцип исторического процесса. Цивилизация. Москва : Наука, 1992. Вып. 1. 231 с.

15. Образцов П.И. Методы и методология психолого-педагогического исследования. Санкт-Петербург : Питер, 2004. 268 с. 
16. Павко А.І., Курило Л.Ф. Вітчизняна університетська педагогічна освіта в імперську добу : історіографічні та методологічні аспекти : монографія. Київ : Знання України, 2005. 120 с.

17. Парадигмальний підхід як концептуальна основа вищої педагогічної освіти. Професійна освіта: иіннісні орієнтири сучасності : зб. наук. праць. Київ, Харків : НТУ «ХПІ», 2009. С. 172-179.

18. Поздняков Э.А. Формационный и цивилизационный подходы. Мировая экономика и международные отношения. 1990. № 5. С. 46-59.

19. Прєдборська I.М. Методологічні засади історії педагогіки. Історія педагогіки у структурі професійної підготовки вчителя. Збірник наукових пращь Кам'янець-Подільського державного педагогічного університету. Серія соціально-педагогічна. Вип. 3. Т. 2. Кам'янець-Подільський : Абетка-НОВА, 2003. C. 3-8.

20. Регейло І.Ю. Підготовка наукових і науково-педагогічних кадрів вищої кваліфікації в Україні у XX - на початку XXI століття : монографія. Київ : Освіта України, 2014. 704 с.

21. Руденко В.Н., Гукаленко О.В. Цивилизационно-культурологическая парадигма развития университетского образования. Педагогика. Москва, 2003. № 6. С. 32-40.

22. Сергеев А.Н. Технологическая подготовка будущих учителей в контексте парадигмальной трансформации образования (на примере специальности: 050502.65 - технология и предпринимательство) : дисс. ... д-ра пед. наук : 13.00.08. Тула, 2010. 49 с.

23. Сисоєва С.О., Кристопчук Т.С. Методологія науково-педагогічних досліджень : підручник. Рівне : Волинські обереги, 2013. 360 с.

24. Скалкова Я. Методология и методика педагогического исследования. Москва : Педагогика, 1989. $224 \mathrm{c}$.

25. Таможська I.В. Теоретичні і методичні засади підготовки науково-педагогічних кадрів в університетах України (друга половина XIX - початок XX століття) : дис. ...д-ра пед. наук : 13.00.01. Полтава, $2020.654 \mathrm{c}$.

26. Философский энциклопедический словарь / гл. редакция: Л.Ф. Ильичев, П.Н. Федосеев, С.М. Ковалев, В.Г. Панов. Москва : Советская энциклопедия, 1983. 840 с.

27. Хриков С.М., Адаменко О.В., Курило В.С., Савченко С.В., Ваховський Л.Ц., Лобода С.М., Сташевська I.О. Методологічні засади педагогічного дослідження : монографія. Луганськ : Вид-во ДЗ «ЛНУ імені Тараса Шевченка», 2013. 248 с.

28. Шейко В.М., Кушнаренко Н.М. Організація та методика науково-дослідницької діяльності. Київ : «Знання», 2008. 310 с.

29. Энтов Р. Что может дать цивилизационный подход? Мировая экономика и международные отномения. Москва, 1991. № 5. С. 19-21.

\section{REFERENCES}

1. Adamenko, O.V. (2006). Rozvytok pedahohichnoi nauky v Ukraini v druhii polovyni XX stolittia (1950-2000 rr.) [Development of pedagogical science in Ukraine in the second half of XX century (1950-2000)]. Extended abstract of the doctoral dissertation. Lugansk. 44 p.

2. Belyaev, V. I. (1999). Sovremenny'e podhody' v istoriko-pedagogicheskih issledovaniyah [Modern approaches to historical pedagogical researches]. Pedagogy. No. 6. P. 19-25.

3. Bybyk, S.P., Siuta, H.M. (2006). Slovnyk inshomovnykh sliv: tlumachennia, slovotvorennia ta slovovzhyvannia [Dictionary of foreign words: definition, word formation and usage]. Kharkiv : Folio. $623 \mathrm{p}$.

4. Bobry'shov, S.V. (2007). Metodologiya istoriko-pedagogicheskogo issledovaniya razvitiya pedagogicheskogo znaniya [Methodology of historical pedagogical research of pedagogical thought development]. Extended abstract of the doctoral dissertation. St. Petersburg. 45 p.

5. Vozniuk, O.V. (2014). Nova paradyhma modeliuvannia ta rozvytku istoryko-pedahohichnoho protsesu [New paradigm of modeling and development of historical pedagogical process]. Zhytomyr : ZhDU im. I. Franka. 550 p.

6. Honcharenko, S.U. (1997). Ukrainskyi pedahohichnyi slovnyk [Ukrainian pedagogical dictionary]. Kiev : "Lybid". 374 p.

7. Zahorodnii, Yu.I., Kurylo, V.S., Savchenko, S.V. (2004). Politychna sotsializatsiia studentskoi molodi v Ukraini: dosvid, tendentsii, problemy [Political social involvement of the student body in Ukraine: experience, tendencies, problems]. Kiev : Heneza. 144 p.

8. Zelenska, L.D. (2012). Ucheni rady v systemi diialnosti universytetiv Ukrainy XIX stolittia [Academic Councils in the system of university activity in Ukraine in XIX century]. Doctor's thesis. Kharkiv. 612 p.

9. Kovalchuk, V.V., Moisieiev L.M. (2004). Osnovy naukovykh doslidzhen [Fundamentals of scientific researches]. Kiev: VD "Profesional". 216 p. 
10. Kozlovskyi, Yu.M. (2018). Metodolohiia pedahohichnoho doslidzhennia [Methodology of pedagogical research]. Lviv: Vyd-vo Lvivskoi politekhniky. 196 p.

11. Kornetov, G.B. (2003). Pedagogika: teoriya i istoriya [Pedagogy: theory and history]. Moscow : Izd-vo IRAO. 296 p.

12. Koxanovskij, V.P. (1999). Filosofiya i metodologiya nauki [Science of philosophy and methodology]. Rostov-na-Donu : Feniks. 576 p.

13. Mokliak, V.M. (2019). Rozvytok avtonomii v universytetakh Ukrainy (XIX - pochatok XX stolittia) [Development of university autonomy in Ukraine (XIX - beginning of XX century)]. Doctor's thesis. Poltava. $641 \mathrm{p}$.

14. Novikova, L.I. (1992). Civilizaciya kak ideya i kak ob'yasnitel'ny'j princip istoricheskogo processa [Civilization as an idea and explanatory principle of the historical process]. Civilization. Moscow: Nauka. Vol. 1. $231 \mathrm{p}$.

15. Obrazcov, P.I. (2004). Metody' i metodologiya psihologo-pedagogicheskogo issledovaniya [Methods and methodology of a psychological and pedagogical research]. St. Petersburg: Piter. 268 p.

16. Pavko, A.I., Kurylo, L.F. (2005). Vitchyzniana universytetska pedahohichna osvita v impersku dobu: istoriohrafichni ta metodolohichni aspekty [Domestic university pedagogical education in the imperial era: historiographical and methodological aspects]. Kiev: Znannia Ukrainy. 120 p.

17. Paradyhmalnyi pidkhid yak konseptualna osnova vyshchoi pedahohichnoi osvity [Paradigm approach as conceptual foundations of higher pedagogical education]. Profesiina osvita: tsinnisni oriientyry suchasnosti : zb. nauk. prats. Kiev, Kharkiv : NTU “KhPI", 2009. P. 172-179.

18. Pozdnyakov, E'.A. (1990). Formacionny'j i civilizacionny'j podhody' [Formation and civilization approaches]. Mirovaya e'konomika i mezhdunarodny'e otnosheniya. No. 5. P. 46-59.

19. Priedborska, I.M. (2003). Metodolohichni zasady istorii pedahohiky. Istoriia pedahohiky u strukturi profesiinoi pidhotovky vchytelia [Methodological foundations of the history of pedagogy]. Zbirnyk naukovykh prats Kamianets-Podilskoho derzhavnoho pedahohichnoho universytetu. Seriia sotsialnopedahohichna. Vol. 3. T. 2. Kamenets-Podolsky : Abetka-NOVA. P. 3-8.

20. Reheylo, I.Yu. (2014). Pidhotovka naukovykh i naukovo-pedahohichnykh kadriv vyshchoi kvalifikatsii v Ukraini u XX - na pochatku XXI stolittia [Training academic and academic pedagogical staff of higher qualification in Ukraine in XX - beginning of XXI century]. Kiev : Osvita Ukrainy. 704 p.

21. Rudenko, V.N., Gukalenko, O.V. (2003). Civilizacionno-kul'turologicheskaya paradigma razvitiya universitetskogo obrazovaniya [Civilization and cultural paradigm of university education development]. Pedagogy. Moscow. No. 6. P. 32-40.

22. Sergeev, A.N. (2010). Tehnologicheskaya podgotovka budushchih uchitelej v kontekste paradigmal'noj transformacii obrazovaniya (na primere special'nosti: 050502.65 - texnologiya i predprinimatel'stvo) [Technological training of future teachers in the framework of paradigm transformation in education]. Doctor's thesis. Tula. $49 \mathrm{p}$.

23. Sysoieva, S.O., Krystopchuk, T.Ye. (2013). Metodolohiia naukovo-pedahohichnykh doslidzhen [Methodology of scientific pedagogical researches]. Rivne: Volynski oberehy. $360 \mathrm{p}$.

24. Skalkova, Ya. (1989). Metodologiya i metodika pedagogicheskogo issledovaniya [Methodology and methods of pedagogical researches]. Moscow : Pedagogika. $224 \mathrm{p}$.

25. Tamozhska, I.V. (2020). Teoretychni i metodychni zasady pidhotovky naukovo-pedahohichnykh kadriv v universytetakh Ukrainy (druha polovyna XIX - pochatok XX stolittia) [Theoretical and methodological foundations of academic staff training in Ukrainian universities (second half of XIX - beginning of XX century)]. Doctor's thesis. Poltava. $654 \mathrm{p}$.

26. Ilichyov, L.F., Fedoseev P.N., Kovalev S.M., Panov V.G. Filosofskij e'nciklopedicheskij slovar' [Philosophical Encyclopedic Dictionary]. Moskow : Sovetskaya e'nciklopediya, 1983. 840 p.

27. Khrykov, Ye.M., Adamenko, O.V., Kurylo, V.S., Savchenko, S.V., Vakhovskyi, L.C., Loboda, S.M., Stashevska, IO. (2013). Metodolohichni zasady pedahohichnoho doslidzhennia [Methodological foundations of a pedagogical research]. Lugansk: Vyd-vo DZ "LNU imeni Tarasa Shevchenka". 248 p.

28. Sheiko, V.M., Kushnarenko, N.M. (2008). Orhanizatsiia ta metodyka naukovo-doslidnytskoi diialnosti [Organization and methodology of scientific research activity]. Kiev : "Znannia". 310 p.

29. E'ntov, R. (1991). Chto mozhet dat' civilizacionny'j podhod? [What is a civilization approach for?]. Mirovaya e'konomika i mezhdunarodny'e otnosheniya. Moskow. No. 5. P. 19-21. 